tar oils, using ultrasonic extraction equipment, to produce a smokeless fuel with coal extract as a by-product. A further step was taken towards the establishment of the absolute significance of measurements of surface areas of coals and carbonized coals by the heat of wetting method. A list of reports and published papers is appended.

\title{
JUBILEE OF ESKDALEMUIR OBSERVATORY
}

E SKDALEMUIR Observatory, the geomag=-3tic and meteorological observatory in a remote situation in north-east Dumfriesshire, was founded on May 11,1908 . It was established because the westward extension of electric tramways from London rendered the magnetic observations at Kew Observatory insufficiently exact for many purposes. Compensation of $£ 10,000$ was paid by the tramway company to the National Physical Laboratory, under which the geomagnetic work at Kew Observatory then coume, and this money was used to build Esk. dalemuir Observatory. The site is reputed to have been chosen by placing a coin on a map so as not to intersect any town or railways within 10 miles. Eskdalemuir came with Kew under the control of the Meteorological Office in 1910.

The history of geophysical work at Eskdalemuir and plans for the future are given by the present superintendent, Mr. M. J. Blackwell, in the May 1958 number of the Meteorological Magazine.

The Observatory has been throughout a first-order geomagnetic and meteorological observatory. Until 1925 , in which year the seismographs were transferred to Kew, it was also a seismological observatory.

Three sets of magnetic instruments, each set recording horizontal force, declination and vertical force, are now in use. The three sets are of different sensitivity and traversing rate and serve different purposes. The magnetographs are in a non-magnetic underground house, the temperature of which is thermostatically controlled. Absolute observations of the magnetic elements are also made, of course. It is interesting to note that the declination of $18^{\circ}$ W. in 1908 has now decreased to less than $11^{\circ} \mathrm{W}$. The records of the magnetographs are analysed at the Observatory, work which continually becomes more complex.

In meteorology and atmospheric physics, extensive work is done in climatology, solar radiation, atmospheric ozone and atmospheric electricity, to mention but a few of the main activities. The apparatus for measuring precipitation includes a variety of standard and experimental rain and snow gauges. Special observations undertaken during the present International Geophysical Year are chemical sampling of air and rain-water, measurements of evaporation and investigation of the vertical distribution of ozone.

The situation of the Observatory has meant that accommodation has to be provided for all the staff, with associated domestic workers, who form a small community - in early years a very isolated one.

Mr. J. Crichton, a former superintendent of Eskdalemuir, wrote in the Meteorological Magazine in 1950 : "So far no encroachment by artificial (magnetic) disturbance has taken place". In expressing good wishes to the Observatory for its next fifty years, we can hope that the happy state of absence of artificial disturbance will continue.

\section{FORESTRY POLICY IN BRITAIN}

\section{$\mathrm{T}$} HE Minister of Agriculture, Fisheries and Food, Mr. J. Hare, in a statement on forestry policy in the House of Commons on July 24, said that the Government had reviewed the position and decided to fix the planting programmes of the Forestry Commission for periods of ten years at a time. For 1959-63 the programme would be about 300,000 acres, and for 1964-68 it would be reduced to about 235,000 , when the Commission's existing plantations began to come into full production. The size of subsequent programmes would be reviewed in five years time in the light of the national needs, and in deciding when planting should take place, special attention would be paid to the upland areas, particularly in Scotland and Wales, where expansion of forestry would provide needed diversification of employment and important social benefits.

The Government proposed to continue its support to private woodland owners, particularly through the dedication scheme, but the present maintenance grant of $5 s .6 d$. per acre would be replaced by a management grant of $18 s$. per acre on the first 100 acres, 12s. on the next 100 and $7 s$. per acre on the rest. The planting grant would be continued, but for approved woodlands would be raised from one half to the full rate per acre. These increased grants are contingent on the formation of an effective woodland owners' association, as recommended by the Watson Committee. The grants for thinning and poplar planting would be terminated, and, in reviewing in future years the level of grants, trends in receipts for private woodlands as a whole as well as trends in costs would be considered. Eventually-in twenty to thirty years time-the level of assistance needed by way of planting and management.grants should become nominal. The system of felling licences would be continued; a statutory instrument would eliminate the need for a licence for fellings in dedicated woodlands, and in general licences would be freely granted for other fellings, subject to the existing arrangements for consultation with planning authorities. Normally, licences would be conditional upon restocking. In reply to questions, Mr. Hare said that the Forestry Commission would consult the woodland owners' organizations in assessing trends in receipts and costs, that his Department was working in the closest possible co-operation with the Secretary of State for Scotland and the Forestry Commission and that there would be no interference with the assistance now given by the Commission to farmers who sought to replant scrub land and land covered with bushes and trees. 